\title{
Does the tripartite social capital predict resilience of supply chain managers through commitment?
}

\author{
Isyaku Salisu $^{a^{*}}$, Norashidah Hashim ${ }^{\mathrm{b}}$, Rahida Aini Mohd Ismail ${ }^{\mathrm{c}}$ and Aliyu Hamza Galadanchid
}

\author{
${ }^{a}$ Department of Business Administration, Umaru Musa Yar'adua University Katsina (UMYUK), Katsina State, Nigeria \\ ${ }^{b}$ School of Business Management, Universiti Utara Malaysia (UUM) Sintok, Malaysia \\ ${ }^{c}$ School of Government, Universiti Utara Malaysia (UUM) Sintok, Malaysia \\ ${ }^{d}$ Bursary Department, Ulul Albab Science Secondary School, Katsina, Katsina State, Nigeria
}

\begin{tabular}{l}
\hline C H R O N I C L E \\
\hline Article history: \\
Received October 12, 2018 \\
Accepted December 202018 \\
Available online \\
December 202018 \\
\hline Keywords: \\
Bonding \\
Bridging \\
Linking \\
Managers commitment \\
Resilience \\
Supply Chain
\end{tabular}

\section{A B S T R A C T}

\begin{abstract}
Studies on supply chain resilience have been well documented, but most of these studies were conducted at organizational level and hence the role of facilitating managers in the supply chain is conspicuously neglected. The purpose of this paper is to explore the effect of tripartite social capital (bonding, bridging and linking) on managers' resilience building and to examine the underlying mechanism through which these relationships exist. Data were collected through selfadministered questionnaire from 452 supply chain managers in Nigeria, a country that has been rocked by series of environmental turbulences. The measurement and structural models were assessed by Partial Lease Square Structural Equation Modelling (PLS-SEM) using SMART-PLS 3 software. The findings suggest that linking social capital influenced manager's resilience, but bonding and bridging did not. Bonding, bridging and linking influence manager's commitment. Additionally, manager's commitment mediated the relationship between tripartite social capital and manager's resilience, Theoretical, practical and methodological implications were also discussed.
\end{abstract}

(C) 2019 by the authors; licensee Growing Science, Canada

\section{Introduction}

Recently, there have been a lot of undesirable events and persistent hitches that have ruthlessly upset the ability of the firms' managers in the products productions and distribution, including, terrorism, political crises, natural disasters and diseases (Aqlan \& Lam, 2015; Chen et al., 2013; Ivanov et al., 2017; Sreedevi \& Saranga, 2017). Such happenings have created mindfulness among both policy makers, practitioners and academics of the need to curtail the potentially devastating effects and consequences of interruptions by creating more resilient supply chains (Elluru et al., 2017). For example, World Economic Forum (2013) survey discovered that more than $80 \%$ of firm's managers are seriously concerned about their supply chains resilience. Additionally, the notion of facing up to interruptions by constructing supply chain resilience (SCRES) has lately garnered substantial academic interest (Das, 2014; Datta, 2017; Elluru et al., 2017). Building SCRES presumes that firms and their managers can swiftly recover from a disrupting incidences - either progressing to an even better state of desired outcome or, at least, returning to normalcy (Li et al., 2017; Macdonald et al., 2018; Mandal

* Corresponding author

E-mail address: abdaratsauri@gmail.com (I. Salisu) 
\& Sarathy, 2018; Tukamuhabwa et al., 2015) Indeed, a firm that possesses a defense and response mechanisms to a disruption performs superior than its competitors and the managers are more committed. In the current study therefore, we identify factors which are precursors impacting resilience of managers to supply chain disruptions. In the limited past empirical studies on SCRES, the attention has been on the industrialized world. Yet firms' managers in emerging nations who constitute a substantial part of total supply chains and have also sustained the devastating effects of supply chain disruptions were conspicuously neglected. Further, majority of the studies put more emphasis on organizational level outcomes such as supply chain performance (Ul-Hameed et al., 2019) and there is a need for more studies on SCRES at individual level in emerging economies.

In spite of growing loss of lives and properties as a result of series of crises, political insecurities and natural disasters, policy makers as well as researchers focused heavily on physical infrastructures in response to such events overlooking the central role of social capital in driving resilience (Aldrich \& Meyer, 2015; Pfefferbaum et al., 2017; Weichselgartner \& Kelman, 2015). Social capital refers to "features of social organization, such as trust, norms, and networks, that can improve the efficiency of society by facilitating coordinated actions." (Putnam, 1993, p.167). According to Aldrich and Meyer, (2015), individuals' acquaintances function as good opportunities for accessing variety of tangible and intangible resources both before, during and afterward of crises or disasters. More so, another abandoned issue in resilience building is commitment defined as a "volitional psychological bond reflecting dedication to and responsibility for a particular target" (Klein et al., 2012, p137). Managers with high level of commitment have all what it takes to continue no matter there is hardship or disruptions. This paper therefore, argued that supply chain managers who suffer setbacks are more likely to be resilient when they possess large chunk of social acquaintances and resources and are committed to their targets.

In Nigeria, like any other developing economies, business managers are facing different degrees of shocks and disruptions as a result of political unrest, religious crisis such as Boko Haram and other forms of social crises. Consequently, it has been estimated that 70 to $80 \%$ of the businesses terminate prematurely, usually within 3-5 years of their startup. However, the surviving ones have devised different strategies to cope with, recuperate from and prevent the future occurrences (Bernier \& Meinzen-Dick, 2014). Central to these but understudied, is the key role of social capital (Aldrich \& Meyer, 2015) and commitment (Yang \& Danes, 2015) of these managers in building resilience. The main purpose of this paper is to empirically examine the supply chain managers' resilience in a developing country, specifically, Nigeria.

The paper is organized as follows. The first section focuses on a review of related literature on the constructs of the study. The second section explains the methodological approach. The third section presents the analyses, results and discussions. The fourth part presents the findings and discussion before finally conclusions and suggestions for future study.

\section{Review of Literature}

In this modern-day business environment, no organizations and individuals can survive against disruption and retain their competitive advantage as a sovereign entity (Bhamra et al., 2011). Defined as individuals' ability to adapt to, and recover from disturbing events (Cheshire et al., 2015), resilience has garnered currency in the literature as a result of several catastrophes and disasters most especially related to supply chain (Elluru et al., 2017; Li et al., 2017; Macdonald et al., 2018; Mandal \& Sarathy, 2018). In an attempt to lessen the consequences of disruptions and crises, many empirical studies explore different predictors as well as antecedents of resilience in the context of supply chain such as supply chain relationships (Mandal \& Sarathy, 2018) supply chain risk management strategies (Zineb et al., 2017), supply chain capabilities (Brusset \& Teller, 2017) and technological capabilities (Rajesh, 2017). The current paper explores the social capital and commitment as the predictors of resilience of supply chain managers in Nigeria. It has been argued that, the more social capital possessed by

individual, the greater the chance of achieving chosen outcome (Chen et al., 2015; Ryu, 2015). The 
concept is rooted in sociology (Qin \& Huang, 2011) and was first used by Durkheim in 1897 when investigating the effect of social influence on suicide (Durkheim, 1951). Putnam distinguishes social capital into bonding and bridging. The latter is the horizontal norms of reciprocity, trust and social relations that is based on familiarity, likeness and intimacy, developing relations and strong ties in the group, normally among intimate associates, families or within community. While the former is horizontal trust, norms of reciprocity and social relations that take place in asymmetrical relationships. It can be thought as a channel that link plots of land or countries that are different in terms of their resources they possess, populations and size (Robison \& Ritchie, 2016). So many researchers embraced this classification to predict various outcomes (Chen et al., 2015). Further, the facet of bridging has also been stretched to integrate linking social capital, which centers around the vertical bridging of power as well as resources through various ranks of society and influence (Ooi et al., 2015). This was incorporated by Woolcock (2001). He argued that social capital is composed of three dimensions bonding, bridging and linking. While bonding, bridging represent horizontal norm and reciprocity, linking represents the vertical norm of reciprocity (Oksanen et al., 2010). This additional facet is regarded as "the capacity to leverage resources, ideas and information from formal institutions beyond the community" (Woolcock, 2001, p.72). It encompasses larger heterogeneity among individuals with diverse ranks of power and is frequently found in peoples' relationships with institutions (Zhou \& Kaplanidou, 2017). In terms of disaster management linking social capital is mostly vital as it links disaster-affected individual with needed resources accessible from the government and from other various donor agencies, networks and disaster-related organizations. This form of capital derives often from enriched information about, and access to, various government aid programs employed to help survived victims access business loans, reconstruct their homes and recuperate emotionally (Pfefferbaum et al., 2017). We included it in our analysis based on Taruvinga et al. (2017) observation that most of empirical research on linking social capital in the literature adopt qualitative approach (e.g. Lang \& Novy, 2014; Ooi et al., 2015; Zhou \& Kaplanidou, 2017) hence called for more quantitative studies on linking social capital. Although previous literature on networks have documented that social capital led to several key economic advantages such as success (Butticè et al., 2017), performance (Meiseberg, 2015), well-being (Matsushima \& Matsunaga, 2015) and happiness (Bartolini \& Sarracino, 2014), the current paper concentrates on the social capital, commitment and resilience of supply chain managers.

\subsection{Managers Social Capital and Resilience}

In the emerging literature on the fundamentals influences of resilience, social capital has gradually been recognized as having a very fundamental role (Jordan, 2015) and it is one of the concepts which contribute impressively to resilience (Goulden et al., 2013). According to American Psychological Association, (2016), the primary element in resilience is having compassionate and helpful relationships. Such relationships that promote love and trust and offer reassurance and inspiration to help in boosting resilience. Furthermore, Torres and Marshall (2015) buttressed that although immediate and interim relief of resources are essential for managers' recovery, evidence advocates that social capital can have positive enduring effects. The widespread prominence of the concept and how it aids resilience might be linked to the overall need to react to crisis, diseases, and, natural disaster. Accordingly, more investigations are rising describing the striking role of social capital. According to social capital theory, network resources are as critical as tangible resources in promoting resilience (Aldrich, 2017). Aldrich (2012) seminal work has provided a good starting point for the study of the link between social capital and individual resilience. The study underlined the critical role of social capital in helping individuals recover from, adjust and even prepare for environmental uncertainties. The work explains the way social resources help after disasters and how configuration of linking, bridging and bonding functions in the process of recovery, hence, managers who are victims of environmental shocks will have upper hand if they possess robust social network because they can simply obtain the required resources that would facilitate lasting recovery. To clarify more, Abramson et al. (2014) model of resilience - Resilience Activation Framework, explains how access to social resources inspires adaptation and fast restoration after disaster. It has offered a groundwork for 
assessing the extent to which access to formal and informal social resource inspires resilience and positive adaptation of people who suffer from different degree of shocks and disasters.

Additionally, other scholars describe the possible advantages of social capital, specially, bridging and bonding forms of social capital in fostering resilience. For instance, bonding allows individual to see indications of the impending danger thereby make adequate preparations (Hawkins \& Maurer, 2010) and it is the most readily accessible resource to secure the resilience building (Aldrich \& Meyer, 2015). Bridging also helps in providing key information and resources that aid in rapid and continual recovery as it generates employment and other daily-life prospects which was not provided by the strong ties (Hawkins \& Maurer, 2010). Further, Goulden et al. (2013) argued that, in order to adequately prepare for environmental uncertainties, individuals rely heavily on both bonding and bridging with the latter having much impact. Furthermore, several empirical studies were carried out to elucidate the relationship between social capital and resilience in different contexts (Beekman et al., 2009; Bernier $\&$ Meinzen-Dick, 2014; Chiesi, 2014; Pal et al., 2014). For instance, the empirical study of influence of social capital on business owners resilience by Torres and Marshall, (2015) has unequivocally shown the dominant role of social capital in building resilience. The study interviewed 450 small business owners in Mississippi after Katrina. They found that, prior, during and after the incidence, small business owners with huge collection of social capital reported higher level of resilience. Moreover, small business owners that are well linked with community and other institutions are presumably well equipped to immediately prevent and or react to any business disaster and build resilience. While both are required, bonding was more essential than bridging in building resilience. Although there were quite a number of studies which relate social capital to resilience, very few (e.g. Bhattacharjya, 2018; Dubey et al., 2017) related them in the context of supply chain. We therefore propose:

H1 - There is a positive relationship between bonding and resilience of supply chain managers.

H2 - There is a positive relationship between bridging and resilience of supply chain managers.

H3 - There is a positive relationship between linking and resilience of supply chain managers.

\subsection{Managers Social Capital and Commitment}

Critical review of literature has shown that social capital has been primarily one of the key elements of individual commitment (Aküzüm \& Tan, 2014; Brien et al., 2015). This relationship has been assessed in different fields of endeavours and the majority of the studies have documented positive relationship (Salisu et al., 2019; Wu \& Chen, 2018; Yang, 2018; Yang et al., 2017). For instance, Bozionelos, (2008) studied the intra-organizational network resources and their relationships with organizational commitment. Their findings suggest that the constructs were highly related. Esmeili et al. (2014) found positive relationship between relational and cognitive social capital \& affective, continuous, and normative components of commitment. Further, Nangoli et al. (2013) documented that elements of social network have significantly predicted commitment. Therefore, commitment is more likely to upsurge when managers possess resource through both their internal and external contact (Wu \& Chen, 2018; Yang et al., 2017). thus, we propose:

H4 - There is a positive relationship between bonding and commitment of supply chain managers. H5 - There is a positive relationship between bridging and commitment of supply chain managers. H6 - There is a positive relationship bet linking and commitment of supply chain managers

\subsection{Managers Commitment and Resilience}

Literature suggest that commitment is a key element of the resilient business owners (e.g. Cooper et al., 2013), and despite the assertion of Yang and Danes, (2015) that people with higher level of commitment are the most resilient and Palanc1, (2018) that commitment is among the most important elements that contribute to the high level resilience, majority of works which connect these constructs used the latter to predict the former, (Lee \& Cha, 2015; Hasan, 2016). Until recently, studies on the relationship between commitment as a predictor of resilience were scarce (Altay et al., 2017; Chang et 
al., 2018; Jokštaitė \& Pociūtè, 2014; Mandal \& Sarathy, 2018; McCormick, 2000; Negru-Subtirica et al., 2015; Salisu et al., 2017; Tiet et al., 2010; Yang \& Danes, 2015). For instance, according to Jung and Song, (2018, p.9) "strong commitment not only lessens transaction cost and uncertainty but also contributes further to enhancing disaster resilience for resilient society. As such, strong commitment strengthens disaster resilience in pre, during, and post disasters". Further, study on the relationship of vocational commitment and career adaptability by Negru-Subtirica et al. (2015) found positive relationship between commitment and adaptability. Therefore:

\section{H7- There is a positive relationship between commitment and resilience of supply chain managers.}

Previous studies established that the components of social capital influence commitment of supply chain managers. Further commitment influences the resilience of supply chain managers. Therefore, we argued that social capital influence resilience through commitment. In other words, social capital influence commitment which in turn influence resilience. Hence, we predicted the relationships of social capital and resilience of supply chain managers to be mediated by commitment. This construct was frequently used as an intervening variable in different relationship (Cai et al., 2017; Izogo, 2015; Paul et al., 2016; Yousef, 2017). Yet it has not been used as a mediating variable in the relationship between social capital and resilience of the managers of supply chain. Thus, we posit:

H8 - Commitment mediates the positive relationship between bonding and resilience of supply chain managers.

H9 - Commitment mediates the positive relationship between bridging and resilience of supply chain managers.

H10 - Commitment mediates the positive relationship between bridging and resilience of supply chain managers.

\subsection{Control variables}

In addition to social capital, we postulate that managers' commitment and resilience depend on their age, gender, experience and level of education. These variables are usually incorporated as control variables when examining individuals' psychological state (Yang et al., 2017). We therefore controlled for age, marital status, gender, and education level as prior studies advocated they might be related with the endogenous variables in our model. For instance, these variables were correlated with commitment (Meng et al., 2017; Yang et al., 2017) and resilience (Butler-Barnes et al., 2018; Howell et al., 2018)

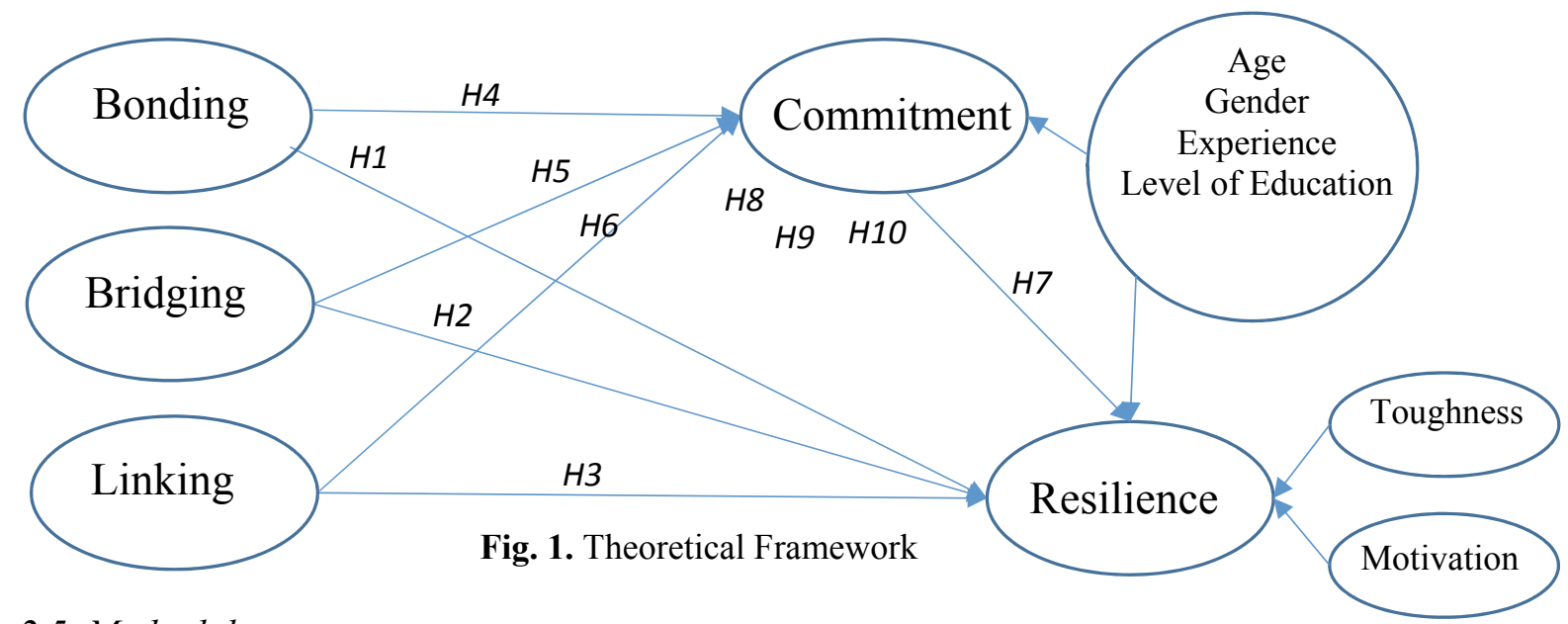

\subsection{Methodology}

This paper collected data from managers of supply chain in Nigeria through self-administered questionnaire. 452 respondents were selected to participate in this study using purposive sampling technique. Descriptive statistics show that most of the participants were males $(89 \%)$ and married 
(73\%). On average, the participants were young, i.e. 35 years old, had 9 years of experience in current industry and 9 years in start-up, and majority (63\%) possesses bachelor or higher qualifications. For the analysis of the data, we use PLS-SEM (Smart-PLS) because it is non-parametric software which exhibits more statistical power then most of the statistical tools available and handles complex models, and has less restriction regarding the normality of the data (Hair et al., 2014).

\subsection{Measures}

All the items in this study were reflective and were adopted from previous studies. One advantage of using this approach is that adopting scales tested in prior research helps to guarantee content validity (Wu et al., 2012). Some of the items were to some extent modified to suit the research context. All items were rated based on five-point Likert scales. Managers' resilience anchored between 'strongly disagree' to 'strongly agree'. Managers' commitment anchored between 'Not at all' to 'Extremely'. For manager's social capital, the response scale for questions assessing managers' rating of their "network size"' was from 'a few' to 'a lot'. The response scale for questions assessing managers' perception of "how many network members"' was form 'none' to 'all'.

Managers' Resilience: We used 10-item Connor and Davidson Resilience Scale 10 (CDRISC 10) validated by (Campbell-Sills \& Stein, 2007) to measure managers' resilience. Previous studies (Ayala $\&$ Manzano, 2014) used CDRISC 25 items to measure the resilience of entrepreneurs. The current study used the condensed 10 items version of it. CDRISC 10 was used in different field of studies, but very few studies used it in the context of supply chain. Sample of the items includes "I think of self as strong person". The psychometric properties of this scale was reported in (Aloba et al., 2016a; Aloba et al., 2016; Blanco et al., 2017) and is considered as the best existing measure of individual resilience (Salisu \& Hashim, 2017a). We use this scale as higher order multidimensional constructs consisting of 'toughness' and 'motivation' validated in the context of the current study (Aloba et al., 2016b).

Managers' commitment was measured by Klein et al. (2014), Unidimensional Target-free (KUT) developed by Klein et al. (2014) considering its psychometric properties, parsimony and less confounding attributes (Breitsohl \& Ehrig, 2017; Klein \& Park, 2016), in line with prior studies (e.g. Herda \& Martin, 2016; Pennaforte, 2016) and in line with the suggestion by Klein et al., (2014) that future studies should adopt the scale to assess various commitment outcomes. In addition, Cannon and Herda (2016), argued, "KUT's conceptual clarity and target-free nature is appealing” (p.72). Example of the questions is "How committed are you to your job and organization".

Managers' Social capital was measured using Wang et al. (2014) 16 items modified personal social capital scale (PSCS 16). The original PSCS was developed by Chen et al. (2009), but later, Wang et al. (2014) reduced the items from 42 to 16 as the PCSC was challenged for being too large and can only be employed for small sample study (Salisu \& Hashim, 2017b). The scale was created as a matrix of five social resources of individuals (relatives, friends, family members, colleagues and neighbours) (Hador \& Eckhaus, 2019). 8 items measuring bonding which focused on four aspects; (1) the number of network members who are reciprocal (2) the perceived network size, (3) the number of network members possessing resources (professional job and social influence), and (4) the number of network members who are perceived as trustful. 8 items measuring bridging which also focused on four aspects; (1) the perceived group size, (2) the resources possessed by these groups (3) whether the groups represent personal rights and interests, and (4) the likelihood to receive help from the groups on request. PSCS 16 is an empirically established and validated scale tested in China and the US (Wang et al., 2016). Sample of the item include, for bonding "Among your relatives how many can you trust?" and for bridging "How many of the governmental, political, economic and social groups/organizations will help you upon your request?". In addition, due to qualitative nature of most studied on linking social capital, there are limited quantitative scales for assessing the constructs, majority of the few studies used the well-known Integrated Questionnaire for the Measurement of Social Capital (SC-IQ tool) by Grootaert et al. (2004) but in this study, linking social capital was measured using 5 items developed 
by Yuan and Ngai (2016). The authors also extracted five items from Chen et al. (2009). The scale asked the managers "to what extent they might request help", "whether they have any connections with institutional agents" and "whether those persons or institutions possess rich information or resources".

\section{Analysis and Results}

Before the assessment of the model, we screen the data to ensure its conformity with multivariate assumptions. Precisely, we use expectation maximization (EM) technique for missing values replacement. We check the data for cases of outlier using Mahalanobis Distance (D2). The test result indicated the data is outliers-free. As the data were collected from one source (managers), there could be the problem of common method variance (CMV). As such, we use two statistical remedies to tackle its effect. First, we ran Harman's one factor test (Podsakoff et al., 2012) which shows no one factor accounted for more than $50 \%$ of the variance. The first factor accounted for only $19.6 \%$. Second, we also employed the more orthodox method for CMV assessment which is viewed as a best test for CMV (Kock, 2015) that depends on comprehensive assessment of the collinearity (Full Collinearity) using Warp-PLS software. As endorsed, the highest variance inflation factors (VIFs) among all the constructs was 2.44 which is less than the benchmark of 3.3 (Kock, 2015). Hence, CMV is not likely to be a serious concern. Further, to confirm the normality of the data, we used Mardia's multivariate normality as suggested by Cain and Zhang, (2016) and Hair et al. (2017). The results indicated that the data did not pass the normality test, kurtosis $(\beta=67.03, p<0.000)$ and skewness $(\beta=2.63, p<0.000)$ and thus, we decided to use the data for the analysis using a Smart-PLS software which non-parametric.

\subsection{Descriptive Analysis of the Latent Constructs}

We computed the latent variables' descriptive statistics using means and standard deviation. The results of the descriptive analysis in Table 1 show that commitment has the highest mean of 4.15 and bridging social capital has the least mean of 2.50 .

Table 1

Descriptive Statistics

\begin{tabular}{cccccc}
\hline Constructs & $\mathrm{N}$ & Minimum & Maximum & Mean & Std. Deviation \\
\hline Linking & 452 & 1 & 5 & 3.4821 & .69151 \\
Bonding & 452 & 1 & 5 & 2.9537 & .65373 \\
Bridging & 452 & 1 & 5 & 2.4924 & .68432 \\
Commitment & 452 & 1 & 5 & 4.1474 & .80638 \\
Motivation & 452 & 1 & 5 & 3.8368 & .58243 \\
Toughness & 452 & 1 & 5 & 3.9592 & .58937 \\
\hline
\end{tabular}

\subsection{Assessment of Measurement Model}

We assess the reflective items to ensure they possess the required reliability and validity. First we determine the individual item reliability by looking at the items loadings while internal consistency reliability by composite reliability (CR). Second, the convergent validity was assessed by examining the loadings, average variance extracted (AVE) as well as CR. As seen in table 2, the loadings were all beyond the standard value of 0.5 (Hair et al., 2014; Hair, Ringle, \& Sarstedt, 2012). CR ranged between $0.853-0.926$ or $>0.708$. The loadings were $>0.6$.

Fornnell and Larcker criteria and the Heterotrait-Monotrait ratio (HTMT) were used to assess discriminant validity, Using Fornell and Larcker (1981) criteria of comparing the square root of the AVE with the correlations among constructs, Table 3 indicates that the off-diagonal values are less than the diagonal (bold) values and hence there is indication of discriminant validity. 
Table 2

Convergent Validity

\begin{tabular}{|c|c|c|c|c|}
\hline Constructs & Items & Loadings & Composite Reliability (CR) & Average Variance Extracted (AVE) \\
\hline \multirow{7}{*}{ Bonding } & BOND1 & 0.814 & 0.886 & 0.532 \\
\hline & BOND2 & 0.797 & & \\
\hline & BOND3 & 0.739 & & \\
\hline & BOND4 & 0.790 & & \\
\hline & BOND5 & 0.770 & & \\
\hline & BOND6 & 0.638 & & \\
\hline & BOND7 & 0.508 & & \\
\hline \multirow[t]{7}{*}{ Bridging } & BRID2 & 0.658 & 0.887 & 0.534 \\
\hline & BRID3 & 0.588 & & \\
\hline & BRID4 & 0.825 & & \\
\hline & BRID5 & 0.784 & & \\
\hline & BRID6 & 0.818 & & \\
\hline & BRID7 & 0.838 & & \\
\hline & BRID8 & 0.539 & & \\
\hline \multirow[t]{4}{*}{ Linking } & LINK1 & 0.631 & 0.806 & 0.514 \\
\hline & LINK2 & 0.875 & & \\
\hline & LINK3 & 0.683 & & \\
\hline & LINK4 & 0.655 & & \\
\hline \multirow[t]{3}{*}{ Motivation } & CDR1 & 0.759 & 0.814 & 0.594 \\
\hline & CDR2 & 0.795 & & \\
\hline & CDR3 & 0.757 & & \\
\hline \multirow[t]{5}{*}{ Toughness } & CDR6 & 0.709 & 0.853 & 0.538 \\
\hline & CDR7 & 0.778 & & \\
\hline & CDR8 & 0.733 & & \\
\hline & CDR9 & 0.721 & & \\
\hline & CDR10 & 0.726 & & \\
\hline \multirow[t]{4}{*}{ Commitment } & KUT1 & 0.831 & 0.904 & 0.703 \\
\hline & KUT2 & 0.849 & & \\
\hline & KUT3 & 0.864 & & \\
\hline & KUT4 & 0.809 & & \\
\hline
\end{tabular}

Table 3

Discriminant Validity Assessment using Fornnell \& Larcker criteria

\begin{tabular}{llcccccc}
\hline SN & Constructs & 1 & 2 & 3 & 4 & 5 & 6 \\
\hline 1 & Bonding & $\mathbf{0 . 7 2 9}$ & & & & & \\
2 & Bridging & 0.329 & $\mathbf{0 . 7 3 1}$ & & & & \\
3 & Commitment & 0.176 & 0.187 & $\mathbf{0 . 8 3 8}$ & & & \\
4 & Linking & 0.201 & 0.162 & 0.223 & $\mathbf{0 . 7 1 7}$ & & \\
5 & Motivation & 0.201 & 0.095 & 0.342 & 0.242 & $\mathbf{0 . 7 7 1}$ & $\mathbf{0 . 7 3 4}$ \\
6 & Toughness & 0.123 & 0.172 & 0.463 & 0.213 & 0.584 & \\
\hline
\end{tabular}

Using heterotrait-monotrait (HTMT) based on the two thresholds of $<0.85$ (Kline, 2016) or $<0.90$ (Gold et al., 2001). When both thresholds are considered, none of the values in the matrix is greater or equal to any of the two benchmarks (see Table 4). In addition, the upper limit confidence intervals were all $<1$.

Table 4

Discriminant Validity Assessment using Heterotrait-Monotrait (HTMT)

\begin{tabular}{|c|c|c|c|c|c|c|c|}
\hline SN & Constructs & 1 & 2 & 3 & 4 & 5 & 6 \\
\hline 1 & Bonding & & & & & & \\
\hline 2 & Bridging & $\begin{array}{c}\mathbf{0 . 4 3 1} \\
(0.341,0.504)\end{array}$ & & & & & \\
\hline 3 & Commitment & $\begin{array}{c}\mathbf{0 . 1 9 1} \\
(0.126,0.253)\end{array}$ & $\begin{array}{c}\mathbf{0 . 1 8 9} \\
(0.107,0.244)\end{array}$ & & & & \\
\hline 4 & Linking & $\begin{array}{c}\mathbf{0 . 2 8 1} \\
(0.179,0.393)\end{array}$ & $\begin{array}{c}\mathbf{0 . 2 2 1} \\
(0.130,0.308)\end{array}$ & $\begin{array}{c}\mathbf{0 . 2 7 4} \\
(0.189,0.365)\end{array}$ & & & \\
\hline 5 & Motivation & $\begin{array}{c}\mathbf{0 . 2 6 0} \\
(0.165,0.349)\end{array}$ & $\begin{array}{c}\mathbf{0 . 1 1 3} \\
(0.068,0.140)\end{array}$ & $\begin{array}{c}\mathbf{0 . 4 5 3} \\
(0.353,0.532)\end{array}$ & $\begin{array}{c}\mathbf{0 . 3 5 4} \\
(0.237,0.476)\end{array}$ & & \\
\hline 6 & Toughness & $\begin{array}{c}\mathbf{0 . 1 6 4} \\
(0.109,0.187)\end{array}$ & $\begin{array}{c}\mathbf{0 . 1 8 1} \\
(0.099,0.223)\end{array}$ & $\begin{array}{c}\mathbf{0 . 5 6 4} \\
(0.470,0.634)\end{array}$ & $\begin{array}{c}\mathbf{0 . 2 7 1} \\
(0.171,0.340)\end{array}$ & $\begin{array}{c}\mathbf{0 . 8 1 1} \\
(0.711,0.901)\end{array}$ & \\
\hline
\end{tabular}

Note: values in bold represent HTMT ration; values in (parenthesis) represent HTMT inference 


\subsection{Assessment of the Formative Hierarchical Component Model}

As suggested by Becker et al. (2012)we use reflective-formative second order to assess the dependent variable (resilience). We checked for collinearity of the first order construct and the significance of weight of each of the formative constructs (Hair et al., 2016). As presented in the Table 5, constructs were checked for collinearity in the model, i.e. motivation and toughness as predictors of resilience. The variance inflation factor (VIF) values of all the constructs are $<5$ (Hair et al., 2016), indicating that they are distinct and measuring different aspects of resilience. Further, the table shows the first order constructs are significantly related to resilience (Significant at 0.01 ).

Table 5

Hypothesis Testing \& Assessment of the Formative Hierarchical Component

\begin{tabular}{|c|c|c|c|c|c|c|c|c|c|}
\hline \multirow[b]{2}{*}{ Relationships } & \multirow[t]{2}{*}{$\begin{array}{l}\text { Std. } \\
\text { Beta }\end{array}$} & \multirow[t]{2}{*}{$\begin{array}{l}\text { Std. } \\
\text { Error }\end{array}$} & \multirow[t]{2}{*}{ t-values } & \multirow[t]{2}{*}{ p-values } & \multicolumn{2}{|c|}{$\begin{array}{c}\text { Confidence Intervals } \\
\text { (CIs) }\end{array}$} & \multirow[t]{2}{*}{$\mathbf{f}^{2}$} & \multirow[t]{2}{*}{ VIF } & \multirow[t]{2}{*}{ Decision } \\
\hline & & & & & LCI & UCI & & & \\
\hline Bonding $\rightarrow$ MR & 0.048 & 0.049 & 0.973 & 0.166 & -0.049 & 0.121 & 0.003 & 1.176 & Not Supported \\
\hline Bridging $\rightarrow$ MR & 0.036 & 0.047 & 0.758 & 0.224 & -0.039 & 0.111 & 0.001 & 1.185 & Not Supported \\
\hline Linking $\rightarrow$ MR & 0.129 & 0.047 & 2.753 & 0.003 & 0.042 & 0.201 & 0.020 & 1.106 & Supported \\
\hline Bonding $\rightarrow \mathrm{MC}$ & 0.083 & 0.041 & 2.033 & 0.021 & 0.012 & 0.140 & 0.007 & 1.168 & Supported \\
\hline Bridging $\rightarrow \mathrm{MC}$ & 0.149 & 0.044 & 3.358 & 0.000 & 0.055 & 0.204 & 0.021 & 1.160 & Supported \\
\hline Linking $\rightarrow \mathrm{MC}$ & 0.187 & 0.048 & 3.875 & 0.000 & 0.112 & 0.271 & 0.037 & 1.066 & Supported \\
\hline $\mathrm{MC} \rightarrow \mathrm{MR}$ & 0.431 & 0.047 & 9.090 & 0.000 & 0.348 & 0.500 & 0.222 & 1.122 & Supported \\
\hline Bonding $\rightarrow \mathrm{MC} \rightarrow \mathrm{MR}$ & 0.042 & 0.019 & 2.195 & 0.028 & 0.001 & 0.076 & NA & NA & Supported \\
\hline Bridging $\rightarrow \mathrm{MC} \rightarrow \mathrm{MR}$ & 0.053 & 0.020 & 2.636 & 0.008 & 0.015 & 0.092 & NA & NA & Supported \\
\hline Linking $\rightarrow \mathrm{MC} \rightarrow \mathrm{MR}$ & 0.077 & 0.021 & 3.629 & 0.000 & 0.038 & 0.122 & NA & NA & Supported \\
\hline Motivation $\rightarrow$ Resilience & 0.406 & 0.015 & 26.425 & 0.000 & 0.383 & 0.432 & NA & 1.599 & Significant \\
\hline Toughness $\rightarrow$ Resilience & 0.707 & 0.019 & 37.889 & 0.000 & 0.680 & 0.743 & NA & 1.750 & Significant \\
\hline
\end{tabular}

\subsection{Testing of Hypotheses}

As depicted in Table 5 and Fig. 2, we assess the direct effect of bonding, bridging and linking on the manager's resilience and commitment. We found only significant relationship between linking and resilience $(\beta=0.129, \mathrm{t}=2.753, \mathrm{p}=0.003$ and $\mathrm{CI}=0.042,0.201)$, but, there were no significant relationships between bonding and resilience $(\beta=0.048, \mathrm{t}=0.973, \mathrm{p}=0.166$ and $\mathrm{CI}=-0.049,0.121)$, and between bridging and resilience $(\beta=0.036, \mathrm{t}=0.758, \mathrm{p}=0.224$ and $\mathrm{CI}=-0.039,0.111)$, hence, $\mathrm{H} 3$ was supported but $\mathrm{H} 1$ and $\mathrm{H} 2$ were not supported. Further, the effect of bonding, bridging and linking on commitment were significant $\{(\beta=0.083, t=2.033, p=0.021$ and $C I=0.012,0.140)(\beta=0.149, t=3.358, p=0.000$ and $\mathrm{CI}=0.055,0.204)$ and $\{(\beta=0.187, \mathrm{t}=3.875, \mathrm{p}=0.000$ and $\mathrm{CI}=0.112,0.271)$ respectively $\}$, hence $\mathrm{H} 4, \mathrm{H} 5$ and H6 were supported. We also found significant positive relationship between commitment and resilience $(\beta=0.431, \mathrm{t}=9.090, \mathrm{p}=0.000$ and $\mathrm{CI}=0.383,0.432)$, therefore, $\mathrm{H} 7$ was supported. On mediating effect on the other hand, the results in Table 5 also show the mediating role of commitment in the relationship between bonding, bridging and linking \& resilience $(\beta=0.042 \mathrm{t}=2.195, \mathrm{P}=0.028$, $\mathrm{CI}=0.001,0.076, \beta=0.053 \mathrm{t}=2.636, \mathrm{P}=0.008, \mathrm{CI}=0.015,0.092$ and $\beta=0.077 \mathrm{t}=3.629, \mathrm{P}=0.000$, $\mathrm{CI}=0.038,0.122$ respectively), therefore, $\mathrm{H} 8, \mathrm{H} 9$ and $\mathrm{H} 10$ were supported.

\subsection{Assessment of Structural Model}

We examine the explanatory and predictive power to assess the inner model. The former is examined using coefficient of determination $\left(\mathrm{R}^{2}\right)$ and effect size $\left(\mathrm{f}^{2}\right)$. While the latter is examined using predictive relevance $\left(\mathrm{Q}^{2}\right)$. For the $\mathrm{R}^{2}$, bonding, bridging, linking and commitment explained $25 \%$ of total variance of manager's resilience. While bonding, bridging, linking explained $11 \%$ of total variance of commitment. For the $\mathrm{f}^{2}$, commitment contributes more to $\mathrm{R}^{2}(0.222)$ than linking $(0.020)$, bonding (0.003) and bridging (0.001) when predicting manager's resilience. But when predicting commitment, linking contribute more to $\mathrm{R}^{2}(0.037)$ then bonding $(0.007)$ and bridging $(0.021)$. 


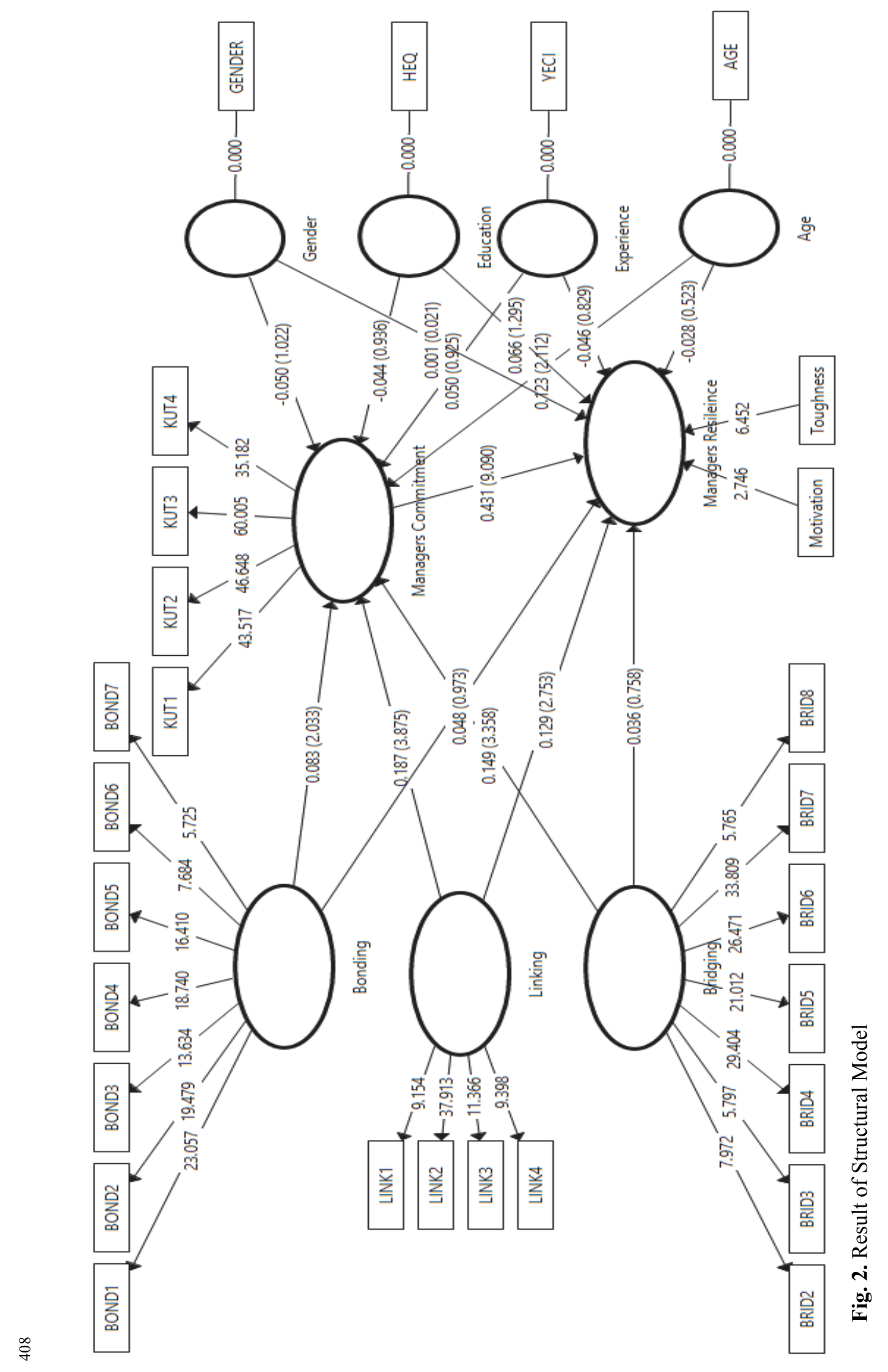


Finally, $\mathrm{Q}^{2}$ was assessed using blindfolding procedure in PLS-SEM. $\mathrm{Q}^{2}$ values $>0$ means that the predictor variable possesses the predictive relevance for the criterion variable (Chin, 2010; Hair et al., 2011). The $Q^{2}$ values of endogenous variable (0.168 and 0.066$)$ signify that the research model has good predictive relevance (see Table 6). Finally, we measure the model fit using standardized root mean square residual (SRMR) (Henseler et al., 2016). The value of SRMR in this paper was 0.069, a value $<0.08$ (Hu \& Bentler, 1999), indicating that the composite factor model fits the data.

\section{Table 6}

Coefficient of determination $\left(\mathrm{R}^{2}\right)$ and predictive Relevance $\left(\mathrm{Q}^{2}\right)$

\begin{tabular}{lcc}
\hline Constructs & $\mathrm{R}^{2}$ & $\mathrm{Q}^{2}$ \\
\hline Managers Commitment & 0.109 & 0.066 \\
Managers Resilience & 0.253 & 0.168 \\
\hline
\end{tabular}

\section{Discussions}

Managers need several forms of resources such as monetary, humans as well as the knowledge, skills, or abilities (KSA) to make things happen. Social capital goes beyond human capital or resources, it centers on not only KSA which individual possesses but also the chain of relationships that they hold. By being connected with other individuals who hold what they need, they can definitely get access to what they require. As hitherto discussed, there are tripartite of social capitals, i.e. bonding, bridging and linking. Bonding connects individuals with related backgrounds so that connections among them in networks become strong. Bridging social capital connects individuals with dissimilar backgrounds who cultivate weak but diverse ties. Linking connects individuals with people in authority. Both of these have benefits and shortcomings depending on one's resource need.

This work delivers a unique approach that adds to the existing literature relating to social capital of managers of supply chain and its impact of commitment and resilience. In specific, we adopt the theoretical framework of social capital (bonding, bridging and linking) to examine its impact on the endogenous variables. Although, so many works have related the variables of this study in various approaches, there are still gaps that remain unattended. This study explored the relationships of these variables in the context of supply chain in Nigeria. As preceding indicated, results provide support for the hypotheses that bonding and bridging are positively related to manager's commitment, but are not related to manager's resilience. Further, linking is positively related to both manager's resilience and manager's commitment. Manager's commitment strongly predicted manager's resilience. The paper also found that manager's commitment plays a mediating role in the relationships between social capital and managers' resilience. Moreover, the findings of the current work corroborate and add to previous supply chain studies in numerous ways. To the best of our knowledge, we have not seen any prior studies that empirically tested the relationships among these variables in the context of supply chain and in a developing country. Thus, this is a novel effort to group these variables into a single structure and assess their relationships.

The findings suggest that supply chain actors, most especially managers that have bonding and bridging relationships can benefit less than those with high linking social capital when aimed at getting the required resources to become resilient. But if commitment is the target, combination of bonding, bridging and linking pays. Although studies (Bernier \& Meinzen-Dick, 2014; Goulden et al., 2013) have documented contrary result from the current study, and, according to Aldrich and Meyer (2015) bonding social capital is the most readily available social resources an individual can acquire in building resilience, this finding also upholds the study by Smith et al. (2012) that although the ability to adapt to unforeseen situation is a product of individuals' compositions of social capital, nevertheless, sometimes social capital could be a barrier to resilience. They argued that not all forms of social capital are beneficial in building resilience. For instance, bonding social capital constrain the readiness to adapt to change. It can enforce stringent norms that can foster homophily, limit group diversity and discourage changes. Bonding can constrain resilience either by enforcing norms that hinder adaptation and innovation or by detaching individuals from required information. Hence they questioned whether 
social capital is really a benefit or "an impediment to resilience?" (p.6). Additionally, Pillai et al. (2017) asserted that social capital has its own disadvantage on some individual and organizational outcomes, and the non-significant findings of this study are not surprising. Further, in the case of commitment, the finding is also corroborated with the previous findings (Aküzüm \& Tan, 2014; Alikhani et al., 2014; Brien et al., 2015; Chang et al., 2018) and according to Ellison et al. (2007), greater access to social capital rises commitment and individual capability to organise collective actions.

Second, the result provides evidence that resilience of supply chain managers often depends on how highly committed they are. The more they are committed, the more they absorb shocks and bounce back. This paper is among limited studies which that explore the relationship between commitment and resilience. Scholars found positive relationship between resilience and commitment (e.g. Lee \& Cha, 2015) but, this study found positive relationship between entrepreneurial commitment and entrepreneurial resilience (inversely). Some studies documented the relationship between these variables (e.g. Negru-Subtirica, Pop \& Crocetti, 2015; Salisu et al., 2017; Yang \& Danes, 2015) and therefore the findings are corroborated with their findings.

Finally, the main theoretical implication of this paper is how manager's commitment could mediate the relationships of social capital and manager's resilience. The finding suggested that the effect of bonding, bridging and linking on manager's resilience were mediated by manager's commitment. The findings suggest that supply chain actors that amass relationship with their strong and weak ties can benefit more by getting the required resources to become resilient if they are committed. This paper therefore argued that although bonding and bridging did not predict manager's resilience, it was influenced through commitment. In other words, because these managers have contacts which guide them to important resources, that is why they are committed and consequently led them to be resilient.

The findings of the current study show the effects of bonding, bridging and linking social capital of supply chain managers on their resilience and the mediating role of their commitment. What does this infer managers? The findings of the current study advocate the conditional impact of bonding, bridging and linking social capital; i.e., examinations on the condition the managers' face should be executed initially. In supply chain, every actor faces different conditions leading to different needs of bonding, bridging and linking. Moreover, the degree of difficulty that the managers experience also differs. Therefore, they need to make a tactical decision of which social capital they highlight and make use of more. Thus, to bond, to bridge or to link is not a matter of "either-or" but "more or less" (Putnam, 2000, p. 23). In other words, these social capital facets are like the multiple edges of a sword. Too much consideration on one facet of social capital in a time of peace can result to the failure of an organization in a time of trouble. Therefore, supply chain managers have to expertly balance bonding, bridging and linking. Findings of the current study advocate that tactical selections among these facets of social capital are made depending on the degree of environmental uncertainty. Consequently, the ideal balancing point may be decided from a comprehensive examination of environmental uncertainty. Practically, however, determining the precise degree of environmental uncertainty may seem to be impossible, but current statistical techniques of analysis may assist the manager in forecasting the degree of environmental uncertainty, and based on these, the managers may be capable of determining which facets or composition of facets of social capital they can lay emphasis on more or less.

\section{Conclusion}

This paper has conveyed novel insight into resilience of managers in the supply chain context and the role of social capital and commitment. The paper has presented ten relationships, seven direct and three mediations. Five direct hypotheses were supported, but two were not supported. In addition, all mediation hypotheses were supported. However, this paper delivered limited thought outside the context in which the data were collected. It is one of uncommon pieces of investigation on predictors of individual resilience in the context of supply chain, but the context of our sample indicated the need for more study of this nature is in other countries. For its significance, and to broaden the findings 
presented in this paper, supply chain managers' resilience requires more investigation especially in developing countries.

\section{Limitations and Future Directions}

This paper has some limitations. As the managers rated themselves in the same measurement context, there could be some elements of CMV and hence, future research should seek to corroborate the current findings by using multiple sources data collection. The nature of this study was cross-sectional, future research should consider longitudinal research design. We also discover that manager's commitment explains manager's resilience and although there were few studies that relate these constructs, there is a need for more studies on how they are related.

\section{References}

Abramson, D. M., Grattan, L. M., Mayer, B., Colten, C. E., Arosemena, F. A., Bedimo-Rung, A., \& Lichtveld, M. (2014). The Resilience Activation Framework: a Conceptual Model of How Access to Social Resources Promotes Adaptation and Rapid Recovery in Post-disaster Settings. Journal of Behavioral Health Services and Research, 42(1), 42-57.

Aküzüm, C., \& Tan, Ç. (2014). Social Capital and Job Satisfaction as the Predictor of the Organizational Commitment. International Journal of Social Science \& Education, 4(3), 729-742.

Aldrich, D. P. (2012). Building Resilience: Social Capital in Post-Disaster Recovery. Chicago, IL: The University of Chicago Press.

Aldrich, D. P. (2017). The Importance of Social Capital in Building Community Resilience. In W. Yan \& W. Galloway (Eds.), Rethinking Resilience, Adaptation and Transformation in a Time of Change (pp. 357-364). Springer International Publishing AG.

Aldrich, D. P., \& Meyer, M. A. (2015). Social Capital and Community Resilience. American Behavioral Scientist, 59(2), 254-269.

Alikhani, A., Fadavi, A., \& Mohseninia, S. (2014). An empirical investigation on relationship between social capital and organizational commitment. Management Science Letters, 4(2), 373-376.

Aloba, O., Ajao, O., Akinsulore, S., Mapayi, B., Alimi, T., \& Esan, O. (2016a). Exploration of the psychometric properties and correlates of the 10 item connor-davidson resilience scale among family caregivers of Nigerian patients with psychiatric disorder. International Journal of Mental Health \& Psychiatry, 2(3).

Aloba, O., Olabisi, O., \& Aloba, T. (2016b). The 10-Item Connor-Davidson Resilience Scale: Factorial Structure, Reliability, Validity, and Correlates Among Student Nurses in Southwestern Nigeria. Journal of the American Psychiatric Nurses Association, 22(1), 43-51.

Altay, B., Gülsüm, B., \& Ihsan, A. İ. (2017). Goal Commitment And Psychological Resilience. European Journal of Physical Education and Sport Science, 3(12), 618-628. https://doi.org/10.5281/zenodo.1146898

American Psychological Association. (2016). What is Resilience?| Psych Central. Retrieved September 18, 2017, from https://psychcentral.com/lib/what-is-resilience/

Aqlan, F., \& Lam, S. S. (2015). Supply chain risk modelling and mitigation. International Journal of Production Research, 53(18), 5640-5656.

Archuleta, A. J., \& Teasley, M. (2013). Acculturative Stress Among People of Mexican Descent: The Role of Acculturation, Social Capital, and Family Role Expectations. Social Work in Mental Health, 11(4), 311-333.

Ayala, J. C., \& Manzano, G. (2014). The resilience of the entrepreneur. Influence on the success of the business. A longitudinal analysis. Journal of Economic Psychology, 42, 126-135.

Bartolini, S., \& Sarracino, F. (2014). Happy for how long? How social capital and economic growth relate to happiness over time. Ecological Economics, 108, 242-256.

Becker, J. M., Klein, K., \& Wetzels, M. (2012). Hierarchical Latent Variable Models in PLS-SEM: Guidelines for Using Reflective-Formative Type Models. Long Range Planning, 45(5-6), 359-394.

Beekman, G., Heide, M. Van Der, Heijman, W. J. M., \& Schouten, A. H. (2009). Social capital and resilience in rural areas: responses to change (No. 48). The Netherlands. Retrieved from http://edepot.wur.n1/14096 
Beigzade, Y., Ghadami, M., \& Amiri, S. S. (2010). A Model for Assessing the Effect of Social Capital on Sustainable Development. Retrieved from https://papers.ssrn.com/sol3/papers.cfm?abstract_id=1655131

Bernier, Q., \& Meinzen-Dick, R. (2014). Resilience and social capital. In Building Resilience for Food \& Nutrition Security. Washington DC: International Food Policy Research Institute.

Bhamra, R., Dani, S., \& Burnard, K. (2011). Resilience: the concept, a literature review and future directions. International Journal of Production Research, 49(18), 5375-5393.

Bhattacharjya, J. (2018). The role of egocentric networks in achieving resilience: a case study from the apparel sector. International Journal of Physical Distribution \& Logistics Management, 48(7), 682-697.

Blanco, V., Guisande, M. A., Sánchez, M. T., Otero, P., \& Vázquez, F. L. (2017). Spanish validation of the 10-item Connor-Davidson Resilience Scale (CD-RISC 10) with non-professional caregivers. Aging and Mental Health, 7863, 1-6.

Bozionelos, N. (2008). Intra-organizational network resources: how they relate to career success and organizational commitment. Personnel Review, 37(3), 249-263.

Breitsohl, H., \& Ehrig, N. (2017). Commitment through Employee Volunteering: Accounting for the Motives of Inter-Organisational Volunteers. Applied Psychology, 66(2), 260-289.

Brien, A., Thomas, N., \& Hussein, A. S. (2015). Turnover Intention and Commitment as Part of Organizational Social Capital in the Hotel Industry. Journal of Human Resources in Hospitality and Tourism, 14(4), 357-381.

Brusset, X., \& Teller, C. (2017). Supply chain capabilities, risks, and resilience. International Journal of Production Economics, 184, 59-68.

Butler-Barnes, S. T., Leath, S., Williams, A., Byrd, C., Carter, R., \& Chavous, T. M. (2018). Promoting Resilience Among African American Girls: Racial Identity as a Protective Factor. Child Development, 89(6), e552-e571.

Butticè, V., Colombo, M. G., \& Wright, M. (2017). Serial Crowdfunding, Social Capital, and Project Success. Entrepreneurship: Theory and Practice, 41(2), 183-207.

Cai, H., Ocampo, A. C. G., Restubog, S. L. D., Kiazad, K., Deen, C. M., \& Li, M. (2017). Career Commitment in STEM. Journal of Career Assessment, 106907271769558.

Cain, M. K., \& Zhang, Z. (2016). Univariate and multivariate skewness and kurtosis for measuring nonnormality: Prevalence, influence and estimation. Behavior Research Methods.

Campbell-Sills, L., \& Stein, M. (2007). Psychometric analysis and refinement of the connor-davidson resilience scale (CD-RISC): Validation of a 10-item measure of resilience. Journal of Traumatic Stress, 20(6), 1019-1028.

Cannon, N. H., \& Herda, D. N. (2016). Auditors' Organizational Commitment, Burnout, and Turnover Intention: A Replication. Behavioral Research in Accounting, 28(2), 69-74.

Chang, H.-Y., Chu, T.-L., Liao, Y.-N., Chang, Y.-T., \& Teng, C.-I. (2018). How do career barriers and supports impact nurse professional commitment and professional turnover intention? Journal of Nursing Management, 1-10.

Chen, J., Sohal, A. S., \& Prajogo, D. I. (2013). Supply chain operational risk mitigation: A collaborative approach. International Journal of Production Research, 51(7), 2186-2199.

Chen, M.-H., Chang, Y.-Y., \& Lee, C.-Y. (2015). Creative entrepreneurs' guanxi networks and success: Information and resource. Journal of Business Research, 68(4), 900-905.

Chen, X., Stanton, B., Gong, J., Fang, X., \& Li, X. (2009). Personal Social Capital Scale: An instrument for health and behavioral research. Health Education Research, 24(2), 306-317.

Chen, X., Wang, P., Wegner, R., Gong, J., Fang, X., \& Kaljee, L. (2015). Measuring Social Capital Investment: Scale Development and Examination of Links to Social Capital and Perceived Stress. Social Indicators Research, 120(3), 669-687.

Cheshire, L., Esparcia, J., \& Shucksmith, M. (2015). Community resilience, social capital and territorial governance. Ager, 4(18), 7-38.

Chiesi, a. M. (2014). Interpersonal Networking and Business Resilience: How Immigrants in Small Business Face the Crisis in Italy. European Sociological Review, 30(4), 457-469.

Chin, W. W. (2010). How to Write Up and Report PLS Analyses. In Handbook of Partial Least Squares (pp. 655-690).

Cooper, C. L., Flint-Taylor, J., \& Pearn, M. (2013). Building Resilience for Success: A Resource for 
Managers and Organizations (1st editio). Palgrave Macmillan, UK.

Das, K. (2014). Integrating resilience in a supply chain planning model. International Journal of Quality \& Reliability Management, 35(3), 570-595.

Datta, P. (2017). Supply network resilience: A systematic literature review and future research. International Journal of Logistics Management, 28(4), 1387-1424.

Dubey, R., Gunasekaran, A., Childe, S. J., Papadopoulos, T., Blome, C., \& Luo, Z. (2017). Antecedents of resilient supply chains: An empirical study. IEEE Transactions on Engineering Management, 1-12.

Durkheim, E. (1951). Suicide: A study in sociology (JA Spaulding \&amp; G. Simpson, trans.). Glencoe, IL: Free Press.(Original Work Published 1897).

Ellison, N. B., Steinfield, C., \& Lampe, C. (2007). The benefits of facebook "friends:" Social capital and college students' use of online social network sites. Journal of Computer-Mediated Communication, 12(4), 1143-1168.

Elluru, S., Gupta, H., Kaur, H., \& Singh, S. P. (2017). Proactive and reactive models for disaster resilient supply chain. Annals of Operations Research, 1-26.

Esmeili, M. R., Vahdati, H., \& Amraei, M. (2014). Investigating the effect of work life quality and social capital on the organizational commitment. Management Science Letters, 4(8), 1741-1750.

Gold, A. H., Malhotra, A., \& Segars, A. H. (2001). Knowledge management: An organizational capabilities perspective. Journal of Management Information Systems, 18(1), 185-214.

Goulden, M. C., Adger, W. N., Allison, E. H., \& Conway, D. (2013). Limits to Resilience from Livelihood Diversification and Social Capital in Lake Social-Ecological Systems. Annals of the Association of American Geographers, 103(4), 906-924.

Grootaert, C., Narayan, D., Jones, V. N., \& Woolcock, M. (2004). Measuring Social Capital. World Bank Working Paper (Vol. 18).

Hador, B. Ben, \& Eckhaus, E. (2019). Effects of Personal Social Capital on Managerial Positions. In J. I. Kantola, S. Nazir, \& T. Barath (Eds.), Advances in Human Factors, Business Management and Society (Vol. 783, pp. 441-450). Cham, Switzerland: Springer International Publishing AG.

Hair, J. F., Ringle, C. M., \& Sarstedt, M. (2011). PLS-SEM: Indeed a silver bullet. The Journal of Marketing Theory and Practice, 19(2), 139-152.

Hair, J. F., Ringle, C. M., \& Sarstedt, M. (2012). Editorial - Partial Least Squares: The Better Approach to Structural Equation Modeling? Long Range Planning, 45(5-6), 312-319.

Hair, J. F., Sarstedt, M., Hopkins, L., \& Kuppelwieser, V. G. (2014). Partial least squares structural equation modeling (PLS-SEM): An emerging tool in business. European Business Review, 26(2), 106-121.

Hair, J. F., Thomas, G., Hult, M., Ringle, C. M., \& Sarstedt, M. (2017). A Primer on Partial Least Squares Structural Equation Modeling (PLS-SEM) (2nd ed). Thousand Oakes, CA: Sage.

Hair, J., Hult, G., Ringle, C., \& Sarstedt, M. (2016). A primer on partial least squares structural equation modeling (PLS-SEM).

Hasan, Z. (2016). Culture as a Mediator between Resilience, Empathy and Commitment. International Journal of Innovative Research And, 1(5), 98-105.

Hawkins, R. L., \& Maurer, K. (2010). Bonding, bridging and linking: How social capital operated in New Orleans following Hurricane Katrina. British Journal of Social Work, 40(6), 1777-1793.

Henseler, J., Hubona, G., \& Ray, P. A. (2016). Using PLS path modeling in new technology research: updated guidelines. Industrial Management \& Data Systems, 116(1), 2-20.

Herda, D. N., \& Martin, K. A. (2016). The effects of auditor experience and professional commitment on acceptance of underreporting time: A Moderated Mediation Analysis. Current Issues in Auditing, 10(2), $14-27$.

Howell, K. H., Thurston, I. B., Schwartz, L. E., Jamison, L. E., \& Hasselle, A. J. (2018). Protective factors associated with resilience in women exposed to intimate partner violence. Psychology of Violence, 8(4), 438-447.

Hu, L., \& Bentler, P. M. (1999). Cutoff criteria for fit indexes in covariance structure analysis: Conventional criteria versus new alternatives. Structural Equation Modeling: A Multidisciplinary Journal, 6(1), 1-55. Imandoust, S. (2011). Relationship between education and social capital. International Journal of Humanities and Social Science.

Ivanov, D., Dolgui, A., Sokolov, B., \& Ivanova, M. (2017). Literature review on disruption recovery in the supply chain. International Journal of Production Research, 55(20), 6158-6174. 
Izogo, E. E. (2015). Journal of Retailing and Consumer Services Determinants of attitudinal loyalty in Nigerian telecom service sector: Does commitment play a mediating role? Journal of Retailing and Consumer Services, 23, 107-117.

Jokštaite, K., \& Pociūtè, B. (2014). Students' Occupational Commitment: Relationship with the Satisfaction of Occupational Choice, Career Aspirations and Career. Psichologija, 49, 60-80.

Jordan, J. C. (2014). Swimming alone? The role of social capital in enhancing local resilience to climate stress: a case study from Bangladesh. Climate and Development, (March), 1-14.

Jung, K., \& Song, M. (2018). The Impact of a Strong Commitment on Disaster Resilience: A Longitudinal Study of the 2012 Korean Typhoons. Journal of Homeland Security and Emergency Management, 111.

Klein, H. J., Cooper, J. T., Molloy, J. C., \& Swanson, J. a. (2014). The assessment of commitment: advantages of a unidimensional, target-free approach. The Journal of Applied Psychology, 99(2), 222238.

Klein, H. J., Molloy, J. C., \& Brinsfield, C. T. (2012). Reconceptualizing workplace commitment to redress a stretched construct: Revisiting assumptions and removing confounds. Academy of Management Review, 37(1), 130-151.

Klein, H. J., \& Park, H. M. (2016). Commitment as a unidimensional construct. In J. P. Meyer (Ed.), Handbook of employee commitment (pp. 15-42). Cheltenham, UK: Edward Elgar Publishing Limited.

Kline, R. (2015). Principles and practice of structural equation modeling (4th Editio). New York, NY: Guilford publications.

Kock, N. (2015). Common method bias in PLS-SEM: A full collinearity assessment approach. International Journal of E-Collaboration, 11(4), 1-10.

Lang, R., \& Novy, A. (2014). Cooperative housing and social cohesion: The role of linking social capital. European Planning Studies, 22(8), 1744-1764.

Lee, E., \& Cha, P. (2015). Effects of work environment and resilience on job satisfaction and organisational commitment of social workers in juvenile reformatory schools. Indian Journal of Science and Technology, 8(1), 360-366.

Li, X., Wu, Q., Holsapple, C. W., \& Goldsby, T. (2017). An empirical examination of firm financial performance along dimensions of supply chain resilience. Management Research Review, 40(3), 254269.

Macdonald, J. R., Zobel, C. W., Melnyk, S. A., \& Griffis, S. E. (2018). Supply chain risk and resilience: theory building through structured experiments and simulation. International Journal of Production Research, 56(12), 4337-4355.

Mandal, S., \& Sarathy, R. (2018). The effect of supply chain relationships on resilience: Empirical evidence from India. Global Business Review, 19(3_suppl), S196-S217.

Matsushima, M., \& Matsunaga, Y. (2015). Social Capital and Subjective Well-Being in Japan. Voluntas, 26(4), 1016-1045.

McCormick, C. (2000). A study of the job attitudes (Job satisfaction, organizational commitment, and career commitment) and career adaptability of the members of the library and information science profession. George Mason University.

Meiseberg, B. (2015). Social capital and start-up performance: The role of customer capital. Interfirm Networks, 125-148.

Meng, H., Luo, Y., Huang, L., Wen, J., Ma, J., \& Xi, J. (2017). On the relationships of resilience with organizational commitment and burnout: a social exchange perspective. The International Journal of Human Resource Management, 1-20.

Nangoli, S., Ahimbisibwe, A., Namagembe, S., \& Bashir, H. (2013). Social networks: a strategy for enhancing project-stakeholder commitment. Journal of Strategy and Management, 6(4), 399-410.

Negru-Subtirica, O., Pop, E. I., \& Crocetti, E. (2015). Developmental trajectories and reciprocal associations between career adaptability and vocational identity: A three-wave longitudinal study with adolescents. Journal of Vocational Behavior, 88, 131-142.

Oksanen, T., Kouvonen, A., Vahtera, J., Virtanen, M., \& Kivimäki, M. (2010). Prospective study of workplace social capital and depression: Are vertical and horizontal components equally important? Journal of Epidemiology and Community Health, 64(8), 684-689.

Ooi, N., Laing Jennifer, \& Mair Judith. (2015). Social capital as a heuristic device to explore sociocultural 
sustainability: a case study of mountain resort tourism in the community of Steamboat Springs, Colorado, US. Journal of Sustainable Tourism, 23(3), 417-436.

Pal, R., Torstensson, H., \& Mattila, H. (2014). Antecedents of organizational resilience in economic crises - An empirical study of Swedish textile and clothing SMEs. International Journal of Production Economics, 147, 410-428.

Palanc1, M. (2018). A prediction of the resilience, subjective well-being and marital adjustment of the parents having children with disabilities based on psycho-social competence. Education \& Science/Egitim ve Bilim, 42(193), 217-236.

Paul, H., Bamel, U. K., \& Garg, P. (2016). Employee Resilience and OCB: Mediating Effects of Organizational Commitment. The Journal for Decision Makers, 41(4), 308-324.

Pennaforte, A. P. (2016). Organizational supports and individuals commitments through work integrated learning. Higher Education, Skills and Work-Based Learning, 6(1), 89-99.

Pfefferbaum, B., Horn, R. L. Van, \& Pfefferbaum, R. L. (2017). A Conceptual Framework to Enhance Community Resilience Using Social Capital. Clinical Social Work Journal, 45(2), 102-110.

Pillai, K. G., Hodgkinson, G. P., Kalyanaram, G., \& Nair, S. R. (2017). The Negative Effects of Social Capital in Organizations: A Review and Extension. International Journal of Management Reviews, 19(1), 97-124.

Podsakoff, P. M., MacKenzie, S. B., \& Podsakoff, N. P. (2012). Sources of method bias in social science research and recommendations on how to control it. Annual Review of Psychology, 63(1), 539-569.

Putnam, R. D. (1993). The Prosperous Community: Social Capital and Public Life. The American Prospect, 13(4), 35-42. https://doi.org/http://www.prospect.org/cs/articles?article=the_prosperous_community

Qin, M., \& Huang, L. (2011). IT/IS innovation behavior formation mechanism: based on ERG theory and social capital. Emergency Management and Management Sciences (ICEMMS), 69-72.

Rajesh, R. (2017). Technological capabilities and supply chain resilience of firms: A relational analysis using Total Interpretive Structural Modeling (TISM). Technological Forecasting and Social Change, $118,161-169$.

Recker, N. (2013). Bonds, Bridges and Quality of Life in Small Towns. Applied Research in Quality of Life, $8(1), 63-75$.

Robison, L., \& Ritchie, B. (2016). Relationship economics: The social capital paradigm and its application to business, politics and other transactions. Routledge, London.

Ryu, S. (2015). To bond or to bridge? Contingent effects of managers' social capital on organizational performance. American Review of Public Administration, 47(4), 403-418.

Salisu, I., \& Hashim, N. (2017a). A critical review of scales used in resilience research. IOSR Journal of Business and Management, 19(4), 23-33.

Salisu, I., \& Hashim, N. (2017b). A critical review of scales used in social capital research. IOSR Journal of Business and Management, 19(04), 34-40.

Salisu, I., Hashim, N., \& Galadanchi, A. (2019). Social capital and entrepreneurial career resilience: The role of entrepreneurial career commitment. Management Science Letters, 9(1), 139-154.

Salisu, I., Hashim, N., Ismail, K., \& Isa, F. M. (2017). Mediating effect of entrepreneurial career resilience between entrepreneurial career commitment and entrepreneurial career success. International Journal of Economic Research, 14(19), 231-251.

Smith, J. W., Anderson, D. H., \& Moore, R. L. (2012). Social capital, place meanings, and perceived resilience to climate change. Rural Sociology, 77(3), 380-407.

Sreedevi, R., \& Saranga, H. (2017). Uncertainty and supply chain risk: The moderating role of supply chain flexibility in risk mitigation. International Journal of Production Economics.

Taruvinga, B., Ndou, P., Hlerema, I. N., Maraganedzha, T. L., Du Plooy, C. P., \& Venter, S. (2017). Fostering linking social capital for successful agricultural development projects in South Africa. Agrekon, 56(1), 28-39.

Tiet, Q., Huizinga, D., \& Byrnes, H. (2010). Predictors of resilience among inner city youths. Journal of Child and Family Studies, 19(3), 360-378.

Torres, A., \& Marshall, M. (2015). Does Social Capital Explain Small Business Resilience? A Panel Data Analysis Post-Katrina. Agricultural \& Applied Economics Association and Western Agricultural Economics Association Joint Annual Meeting. San Francisco.

Tukamuhabwa, B. R., Stevenson, M., Busby, J., \& Zorzini, M. (2015). Supply chain resilience: Definition, 
review and theoretical foundations for further study. International Journal of Production Research, 53(18), 5592-5623.

Ul-Hameed, W., Shabbir, M. S., Imran, M., Raza, A., \& Salman, R. (2019). Remedies of low performance among Pakistani e-logistic companies: The role of firm's IT capability and information communication technology (ICT). Uncertain Supply Chain Management, 7, 369-380.

Unni, A. S. V. (2014). A Study of Relationship between Social Capital and Organizational Citizenship Behavior. International Journal of Managerial Studies and Research (IJMSR), 2(4), 76-81.

Wang, C., Zhu, J., Cai, Y., Cui, D., Wang, Q., \& Mao, Z. (2016). Community-Based Study of the Relationship between Social Capital and Cognitive Function in Wuhan, China. Asia-Pacific Journal of Public Health, 28(8), 717-724.

Wang, P., Chen, X., Gong, J., \& Jacques-Tiura, A. J. (2014). Reliability and Validity of the Personal Social Capital Scale 16 and Personal Social Capital Scale 8 : Two Short Instruments for Survey Studies. Social Indicators Research, 119(2), 1133-1148.

Weichselgartner, J., \& Kelman, I. (2015). Geographies of resilience: Challenges and opportunities of a descriptive concept. Progress in Human Geography, 39(3), 249-267.

Woolcock, M. (2001). The place of social capital in understanding social and economic outcomes. Canadian Journal of Policy Research, 2(1), 1-35. Wu, C., \& Chen, T. (2018). Collective psychological capital: Linking shared leadership, organizational commitment, and creativity. International Journal of Hospitality Management, 74(May 2017), 75-84.

Wu, X., Zhou, H., \& Wu, D. (2012). Commitment, satisfaction , and customer loyalty: a theoretical explanation of the 'satisfaction trap .' The Service Industries Journal, 32(11), 37-41.

Yang, G. (2018). The Social and Organisational Determinants of School Commitment of Expatriate Teachers. Journal of Research in International Education, 17(1), 33-48.

Yang, X., Li, G., \& Huang, S. (2017). Perceived Online Community Support, Member Relations, and Commitment: Differences between Posters and Lurker. Information and Management, 54(2), 154-165.

Yang, Y., \& Danes, S. M. (2015). Resiliency and Resilience Process of Entrepreneurs in New Venture Creation. Entrepreneurship Research Journal, 5(1), 1-30.

Yousef, D. A. (2017). Organizational Commitment, Job Satisfaction and Attitudes toward Organizational Change: A Study in the Local Government. International Journal of Public Administration, 40(1), 7788.

Yuan, R., \& Ngai, S. S. Y. (2016). Agentic personality as mediator of social capital on developmental outcomes in the transition to adulthood: Evidence from Shanghai, China. Journal of Adolescence, 46, 113.

Zhou, R., \& Kaplanidou, K. (2017). Building social capital from sport event participation: An exploration of the social impacts of participatory sport events on the community. Sport Management Review, 1-13.

Zineb, E., Brahim, B., \& Houdaifa, A. (2017). The impact of SCRM strategies on supply chain resilience: A quantitative study in the Moroccan manufacturing industry. International Journal of Supply Chain Management, 6(4), 70-75.

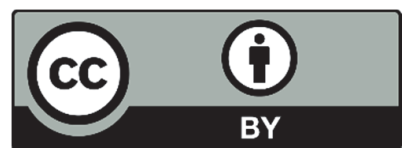

(C) 2019 by the authors; licensee Growing Science, Canada. This is an open access article distributed under the terms and conditions of the Creative Commons Attribution (CC-BY) license (http://creativecommons.org/licenses/by/4.0/). 